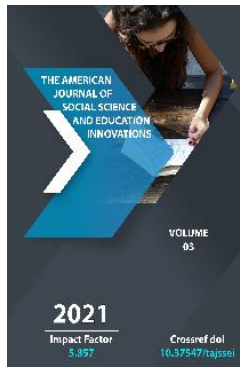

\title{
Teaching English As A Foreign Language To Students With Learning Disabilities
}

\author{
Razzakova Gulchekhra Rustamovna \\ Tashkent University Of Information Technologies Named After Muhammad Al-Khwarizmi \\ Senior Teacher Of The Department Of Foreign Languages, Uzbekistan
}

\footnotetext{
Journal Website: http://usajournalshub.c om/index,php/tajssei

Copyright: Original content from this work may be used under the terms of the creative commons attributes 4.0 licence.
}

\section{ABSTRACT}

Foreign language study is an increasingly prominent part of education everywhere. Not only are high school students nearly always required to study a foreign language, but many lower and middle schools have added foreign languages to their curricula, whether as enrichment or a requirement. While it has long been recognized in the learning disabilities field that foreign language study would be a terrific challenge to learning disabled students, somehow this fact has been widely ignored in the field of foreign language instruction and in schools in general until very recently. The following article looks into the ways to teach foreign languages to students with learning disabilities.

\section{KEYWORDS}

Disorder, disability, language acquisition, interaction. Students with disabilities: concept, characteristics.

\section{INTRODUCTION}

A student with disabilities is a person with physical and (or) mental disabilities that impede the development of educational programs without creating special conditions for obtaining education. 
Under the influence of new value orientations of society and the state, as well as in connection with the transition of the special education system to a qualitatively new stage of development, it became necessary to rethink the relationship between the educational achievements of the child and achievements in the field of social competence, rethinking the role and place of the personal, social development of a child with disabilities.

In the process of interacting with a child with developmental disabilities, many problems arise associated with the influence on the developing personality of a huge number of external and internal factors. To effectively manage this process, you need to know their specifics, positive and negative aspects, anticipate the impact results and make adjustments in a timely manner.

The future of millions of disabled people throughout the country depends on the skill of doctors and their knowledge of the specifics of their work. Very often, due to an incorrect diagnosis of a psychologist, speech therapist or teacher, a small patient loses the only chance for social adaptation. The professional skills of educators should be aimed not only at meeting basic needs, but also at strengthening the motivation of students using special technologies. Every child with disabilities, be it autism, deafness or cerebral palsy (CP), must develop to the best of his ability.

Before drawing up a training plan, children with disabilities are divided into groups according to the degree of health impairment. This approach helps to unite children with similar disabilities and provide them with the most comfortable opportunities for adaptation.

\section{MATERIALS AND METHODS}

How can learn disabled students be taught foreign languages?

Once they had pinpointed what they felt was the root of the foreign language learning problem, Lanchow and Sparks began investigating ways that learning disabled students could be helped to learn a foreign language. At least two approaches to foreign language instruction different from "normal" or traditional language instruction have emerged as being effective.

The first and most researched approach is a response to Lanchow and Spark's findings that many, if not most, students having trouble with foreign language acquisition have phonological deficits in their first language. Lanchow and Sparks theorized further that to help these students, the sound system of the target language must be very explicitly taught. In order to test this theory, Lanchow and Sparks collaborated with a high school Spanish teacher who had learned about the Orton-Gill Ingham method of teaching phonology, reading and spelling to very significantly learning disabled students. In this method, sounds are presented in a highly structured fashion with a great deal of visual, kinesthetic and tactile practice and input. The Spanish teacher, Karen Miller, has tested the effectiveness of teaching Spanish to learning disabled students using the Orton-Gill Ingham approach. The research on her students has shown quite conclusively that LD students taught Spanish in this way have been able to learn and retain it. Another collaborator, Elk Schneider, has had similar results teaching German to LD students.

In their studies on Karen Miller's students, Lanchow and Sparks found that by being 
taught phonological skills in one language, the students improved their phonological awareness in English also. This finding has led to a variation on the method of teaching phonology in the target language: teach the fundamentals of phonology in the student's native language before foreign language instruction begins. That is, students are taught to recognize phonemes, to decode, or read words, efficiently and to encode, or apply the sounds to the written language. Basically, they learn what language is and how its sounds and parts function. Application of this knowledge to the language they are trying to learn is the next step. This has proven an effective remediation as well. In fact, so strongly do Lanchow and Sparks believe this, they now recommend very strongly that such phonological skills be much more heavily stressed when children are learning to read. They feel students' reading and language skills will be much stronger, and future problems with foreign language acquisition will be headed off for many.

The second approach to language instruction which has been effective has been to adapt the foreign language courses according to principles of instruction known to be effective for LD students. This means making such changes as reducing the syllabus to the essential elements, slowing the pace of instruction quite considerably, reducing the vocabulary demand, providing constant review and incorporating as much visual/tactile/kinesthetic (i.e. multisensory) stimulation and support as possible. Many of these course adaptations were also responses to the specific complaints and requests of foreign language students having trouble in their classes. Furthermore, in some schools there are courses designed for the student strong in listening and speaking skills but weak in reading and writing, and vice versa. The University of Colorado at Boulder has shown this latter approach to be effective in Latin and Spanish courses adapted for LD students. A phonological component is part of this adapted curriculum.

Children with disabilities have their own specific characteristics:

Disorders of the emotional-volitional sphere and behavior impaired speech development, lack of one's own speech initiative; impaired attention; decreased performance excessive physical activity inability for purposeful organized behavior

Absent-mindedness, impulsivity hyper excitability problems of verbal communication Limited stock of general information and ideas about the world around. According to the international classification, there are 4 degrees of development of pathologies, in relation to which the patient is assigned a certain status:

Mild to moderate dysfunctions.

Pronounced deviations.

High severity of pathologies.

Pronounced violations.

Children with disabilities of the first degree have pathologies that are often an indication for recognizing disability. However, not all children from this category become disabled, since with proper training and adequate load, they are able to restore lagging body systems in development. The second type includes adult patients with the third group of disabilities and children with severe disabilities. Pathologies limit the possibilities of social 
adaptation of these people, so they need special conditions for life.

The third degree of HVD corresponds to the second group of disability in an adult. Children from this category are severely limited in life processes due to the high severity of health disorders. The fourth degree includes patients with pronounced pathologies of organ functions. Due to the above deviations, people are forced to live in conditions of social maladjustment. Rehabilitation and treatment measures at this stage are rarely successful, since most of the lesions are irreversible.

The formation of an accessible educational environment requires adherence to the rules, since students with disabilities are a special group of students. Training should take place in specially equipped rooms that will guarantee safety. A child with disabilities can receive a full-fledged education only in schools where adapted courses and correction schemes are applied. There is a possibility of sending disabled children to ordinary general educational institutions, where they can study on an equal footing with their peers [9].

The educational process for children with disabilities has some features that are absent in the general education curriculum. The action of the corrective technique is aimed at fully or partially eliminating deviations. For example, while working with children who have visual impairments, teachers use educational computer games. The use of special technologies helps to improve the condition of the visual analyzer in a playful way. The main principles of training are:

Motivation for the educational process;

Psychological safety;
Unity of joint activities;

Assistance in adapting to the environment.

\section{REFERENCES}

1. Acxiom Corporation (2011). Experiences verifying the identity of online students. Acziom Corporation. Al-Ajlouni, K. I. (2015). Learning Effects of Using Learning Management System (Moodle) by Students of Arab Open University. Pp.15-40.

2. Proceedings of MAC-ETel 2015. Multidisciplinary Academic Conference on Education, Teaching and E-Learning, Prague. Al-Amleh, M. (2014). Identifying the Palestinian Culture According To Hofstede's Theory. MA thesis, Jerusalem, occupied Palestinian Territories: Al-Quds University. Alkailani, M., Azzam, I. A., \& Athamneh, A. B. (2012). Replicating Hofstede in Jordan: ungeneralized, reevaluating the Jordanian culture. International Business Research, 5 (4), p.71.

3. American University in Cairo News (2015) Faculty Reform Requires Change in the Mindset of Educators, Youth [Online], Cairo. Available at: http://www.aucegypt.edu/news/storie s/faculty-reform-requireschangemindset-educators-youth (Accessed 27/11/2017) Assaad, R., Salehi-Isfahani, D., \& Hendy, R. (2014). Inequality of opportunity in educational attainment in Middle East and North Africa: evidence from household surveys. In Economic Research Forum Working Paper Series No (Vol. 834). 